\title{
Willingness to migrate-a potential effect of burnout? A survey of Hungarian physicians
}

\author{
Zsuzsa Győrffy ${ }^{1 *}$, Diana Dweik ${ }^{2}$ and Edmond Girasek ${ }^{3}$
}

\begin{abstract}
Background: Burnout worldwide and migration of caregivers are among the most important challenges of the twenty-first century health care.

Methods: Quantitative, online survey of Hungarian physicians ( $n=4784)$ was performed in 2013. A link to an anonymous, self-administered questionnaire was sent to all potential participants, namely to the registered members of the Hungarian Medical Chamber with a valid e-mail address. Linear regression analysis was used to determine the risk factors of burnout. The association between physicians' burnout and their willingness to migrate was determined by binary logistic regression analysis.

Results: Moderate/mild level of personal accomplishment was detected in $65 \%$ of respondents, whereas moderate/ severe level of emotional exhaustion and depersonalization was detected in $49 \%$ and $46 \%$, respectively. Single male physicians younger than 35 composed the cohort with the highest risk for developing burnout. Higher daily working hours and multiple workplaces contribute to the risk of developing burnout.

According to logistic regression analysis, the intention to work abroad was affected by the emotional exhaustion dimension of burnout $(\mathrm{OR}=1.432)$ and depersonalization had a tendency to have an impact on the willingness to migrate.

Conclusions: We assume that there is a circular causality between burnout and the willingness to migrate. Burnout increases the willingness to work abroad, whereas contemplating migration might evoke a certain degree of depersonalization in caregivers who are in a dilemma.
\end{abstract}

Keywords: Burnout, Willingness to migrate, Physicians, Workload, Turnover

\section{Background}

The worldwide healthcare workforce crisis is a permanent problem nowadays. The main factors of this phenomenon are the following: shortage of healthcare workers, aging and burnout of physicians and a higher demand for chronic care. The migration of healthcare workers has also been a highlighted issue in the past four decades. Since the 1970s, migration has become characteristic in all parts of the world (from developing countries to developed ones; from Western Europe to the United States of America; from Western European countries to other Western European

\footnotetext{
* Correspondence: gyorffy.zsuzsa.mail@gmail.com

${ }^{1}$ Institute of Behavioural Sciences, Semmelweis University, Nagyvárad square

4, Budapest $\mathrm{H}-1089$, Hungary

Full list of author information is available at the end of the article
}

countries) [1, 2]. Since the European Union accession in 2004, this issue has become more and more important as a consequence of the vanishing borders that have brought the Western European labour market closer to Hungarian employees [3, 4].

The EU predicts that over the next 50 years, the number of people over the age of 65 will double [5]. In parallel, the average age of the physicians is also rising. According to the EU forecast, around 60000 doctors have to retire within 2 years (2020) in Europe [5]. In Hungary, according to the data of the National Health Service Center, $51 \%$ of the practicing physicians are older than 49 years, whereas the issue of migration affects mostly the young age group [6]. According to the Hungarian data, it is the 55-60-year-old age group that

(c) The Author(s). 2018 Open Access This article is distributed under the terms of the Creative Commons Attribution 4.0 International License (http://creativecommons.org/licenses/by/4.0/), which permits unrestricted use, distribution, and 
is the most populous of all the practicing cohorts of medical doctors, and serious shortage of labour is expected when they retire [6]. For example, the aging of general practitioners and the vacancy of their practice has been one of the main concerns of Hungarian health care for several years. While approximately 200 permanently vacant practices were registered in 2006 and 2007, this figure has become 303 by 2016 . Furthermore, $40 \%$ of the GPs currently practicing in Hungary are older than 60 years of age [7]. In Hungary, the increasing number of participants in medical education could be a potential answer to this issue.

Approximately, 800-600 physicians have set up claim for the certification for working abroad annually between 2010 and 2015 and this number is showing a decreasing trend [8]. However, this number does not necessarily reflect the degree of real migration; rather, it can be a sign of certain physicians' strong intention to work abroad [6]. In fact, just half or one third of these physicians have worked abroad [8]. Among those setting up claim for the official certificate, it is the rate of the 25-29-year-old trainee cohort that shows the most dynamic increase [8].

According to a previous Hungarian study, the most important motivation factors of one's willingness to work abroad are salary, quality of life, working conditions and career options [9]. Both international and domestic research support that along with the growing emphasis on the above-mentioned factors, significant vocational alterations have been witnessed. These studies highlight that intrinsic motivations such as altruism are still crucial but not the only vocational factors [10]. Factors related to 'controllable lifestyle', such as salary, workplace, career options and opportunities of working abroad, are almost equally important compared with the helper motivation.

The issue of burnout is another considerable challenge of the twenty-first century health care. Burnout is the 'state of mental and physical exhaustion caused by one's professional life' [11]. Maslach and Jackson created a multidimensional theory of burnout based on this definition. In this theory, three basic dimensions of burnout are explored: emotional exhaustion, depersonalization (negative attitude toward patients, colleagues and work) and the sense of decreased personal accomplishment, as the third factor [12]. Furthermore, according to Maslach et al., the harmony between the individual and his or her work and working conditions is among the key predictors of burnout. The six components of working conditions are the following: workload, sense of control, strain, workplace community, 'fairness' and harmony of the common values. The lack of these components is the most important moderating factor of burnout [13].

Based on the above-mentioned definitions, burnout is one of the most extensively investigated fields of research related to health care workers. Several studies highlight that burnout of caregivers is not a private issue, since it can have severe impact on the frequency of complications and malpractice [14-16]. According to the meta-analysis of Salyers et al., both patient safety and patient satisfaction are in close correlation with the extent of burnout [17]. Burnout decreases one's efficacy and productivity and increases the number of days out of work, the possibility of leaving the profession and premature retirement $[18,19]$.

\section{Aims of the study}

Several studies have associated the employees' burnout with their leaving the profession $[20,21]$. However, we could hardly find any studies on the potential link between burnout and one's willingness to work abroad. According to our assumption, burnout of caregivers and their willingness to migrate are in potential correlation. In other words, the wish to change one's work and life conditions can be a plausible response to emotional exhaustion, depersonalization and decreased personal accomplishment. The intention to work abroad could fulfil this wish. Our aim was to explore the potential association between the willingness to migrate and the degree of the different dimensions of burnout.

\section{Methods}

A quantitative, online survey of physicians and dentists working in Hungary was conducted between 9 May and 15 July, 2013. The survey was performed with the permission of the Hungarian Medical Chamber. Ethical permission was obtained from the Ethical Committee of Semmelweis University, Budapest (No: 60/2013).

A link to an anonymous, self-administered questionnaire was sent to all potential participants, namely to the registered members of the Hungarian Medical Chamber with valid e-mail address $(n=42342)$, which means 35 867 medical doctor and 6475 dentists. This was followed by four reminder e-mails. Response rate was $13.24 \%(n=5607)$, breaking it down by profession, response rate was $12.71 \%$ among dentists $(n=823)$ and $13.34 \%$ among medical doctors $(n=4784)$. Due to the special nature of their profession, dentists were examined as a separate group. In the present analysis, we limited our attention to medical doctors $(n=4784)$. We considered a questionnaire complete in case the participant responded to at least $90 \%$ of the questions. All international studies emphasize that surveys of physicians have lower response rates compared with the general population even in case of traditional, paper-based surveys $[22,23]$. The response rates of studies of physicians average about $10 \%$ lower than those of the general population. Studies on physician surveys have shown 
that lower response rates were the result of using web surveys alone compared with other survey designs [23].

Data were weighted by gender, age and type of profession (physicians vs. dentists), according to the characteristics of members of the Hungarian Medical Chamber. After three-dimensional weighting (gender, age and type of profession), the distribution of data concerning the region (counties) and type of workplace (general practice, in-patient and out-patient care) were compared with the same type of data from the Hungarian Central Statistical Offices [24]. As a result of the comparison, we found distributional differences neither by regions nor by type of workplace. Therefore, we considered our sample material representative.

\section{Measurements}

During the analysis of socio-demographic data, we used a five-category variable for respondents' age (24-35, 36$45,46-55,56-65$ years old or older than 65 ). We gathered information on marital status and the number of children. In the present analysis, the type of primary workplace was a four-category variable (general practice, out-patient and in-patient care and other). The number of daily working hours, the amount of shift work and the number of workplaces were handled as continuous variables.

For the assessment of burnout, we used Maslach Burnout Inventory $[25,26]$. MBI is a 22-item questionnaire which assesses burnout by three different subscales: emotional exhaustion (EE), depersonalization (DP) and personal accomplishment subscales (PA). A seven-point Likert scale (from zero to six) was used to assess the frequency of certain work-related emotions. The 22 items put up three subscales (EE, DP and PA). EE consists of nine statements and assesses the feelings of being overextended and exhausted in one's workplace (e.g. 'I feel depressed at work'). DP consists of five items and measures an unfeeling and impersonal response toward recipients of one's service, care treatment or instruction (e.g. 'I don't really care what happens to some recipient"). PA consists of eight statements that assess feelings of competence and success in one's work (e.g. 'I have accomplished many worthwhile things in this job') [25].

According to the scores reached on each subscale, severity of burnout is assessed as mild, moderate and severe. Severe burnout among physicians is defined as EE $>27$; DP > 10; $\mathrm{PA}<33$ [25]. The Cronbach alpha of EE, DP and PA in our study was $0.909,0.767$ and 0.818 , respectively.

The willingness to migrate was assessed by the following statement: 'Do you plan to work abroad in the following one or two years?' (yes or no). If the answer was yes, the following question was whether the respondent wished to work abroad as a medical doctor or not.
We also asked if the respondent had already taken any preparative measures in order to work abroad. Response options were the following: 'Yes, I have written contract with a foreign institution'; 'Yes, I have oral contract with a foreign institution'; 'Yes, I am in contact with a foreign institution (via mail or phone)'; 'I do not have a contract yet'; 'I have already inquired about the working options'; 'It is among my future plans'.

\section{Statistical analysis}

Descriptive statistics were used to determine the prevalence of burnout among Hungarian physicians. Linear regression model was used to determine the risk factors of the dimensions of burnout. In the analysis, we examined the impact of several socio-demographic and work-related variables on all three dimensions of burnout, such as gender, age, number of workplaces, number of daily working hours, doing shift work, marital status and type of primary workplace.

After the explanation model of the dimensions of burnout, binary logistic regression model was executed for the two-category variable of the willingness to migrate. In binary logistic regression analysis, we used binary variables of EE, DP as dependent variables, control variables were gender, marital status (single/living with partner) and doing shift work (yes/no) were used as two-category variables, whereas age, number of workplaces, number of daily working hours were continuous variables. We created four-category variables from the variable 'type of primary workplace' (general practice, outpatient department, inpatient department and others).

A threshold of $p<0.05$ was established to consider an association significant. Statistical analyses were conducted using the SPSS 21.0 for Windows.

\section{Results}

\section{Socio-demographic data}

There were 2269 male (47.4\%) and 2515 female (52.6\%) physicians in the study. Mean age of respondents was 52.5 years, the minimum age was 24 years old and the maximum was 84 . (The median age was 52 years.) The age distribution of the sample shows that the two age groups with the largest headcount were those in the 4655 and the 56-65-year-old groups, which formed 10.8\% and $11.9 \%$ of the respondents respectively.

More than two thirds of respondents (69.2\%) were married, $12.1 \%$ were cohabiting, $7.5 \%$ were divorced, $7 \%$ were single and $4.3 \%$ were widowed.

Two fifth $(41 \%)$ of the respondents had two children. Childless was $18.5 \%$ and $18.5 \%$ had one child, while $16.1 \%$ and $4.2 \%$ had three and four children, respectively. The mean number of children was 1.7.

Almost half of the practicing physicians $(48.1 \%)$ had specialization in any field of medicine, $11 \%$ were trainees, 
whereas $16.4 \%$ worked as pensioners. Entrepreneur physicians were $18.4 \%, 2.2 \%$ were university teachers and $0.4 \%$ were researchers. Only $1.5 \%$ was on maternity leave. With regard type of workplace, $42.3 \%$ and $17.6 \%$ worked in in-patient and out-patient care, respectively. One quarter were GPs (25.5\%), and $14.6 \%$ worked somewhere else (civilian organization, civil service or private health care). Almost half $(48.6 \%)$ of the participants had just one workplace. More than one quarter $(25.6 \%)$ and $11.8 \%$ had two or three workplaces, respectively, $5 \%$ had four or more workplaces simultaneously and $9.1 \%$ of the respondents reported having no job at all. The mean number of workplaces was 1.58 .

The mean number of specializations was 1.4. Two fifths $(40 \%)$ of the sample had one, one third had two and almost $11 \%$ had three different specializations, while $13.8 \%$ had no specialization. Information was gathered about the type of the specialization that was first acquired and about the primarily used type (in case of more than one specialization) (Table 1).

\section{Willingness to migrate}

Most of the respondents (82\%) did not plan to work abroad in the forthcoming one or 2 years, whereas $16.6 \%$ and $1.4 \%$ planned to work abroad either as physician or not as physician, respectively.

Among those who plan to work abroad, $17.1 \%$ had written or oral contract, and 50\% were actively searching the options of working abroad (without any contract yet). There were $32.9 \%$ who had plans of migration in the near future but had not taken any measures to contact a foreign health care institution.

\section{Burnout of physicians}

The mean scores of EE, DP and PA were 19.44 $(\mathrm{SD}=$ 12.8), $6.13(\mathrm{SD}=6.1)$ and $34.42(\mathrm{SD}=9.2)$, respectively. Mild, moderate and severe levels of emotional exhaustion were detected in $49.4 \%, 27.1 \%$ and $22.2 \%$ of the respondents, respectively. Mild, moderate and severe levels of depersonalization were detected in 57.3\%, 23.7\% and 19\% of the respondents, respectively. Mild, moderate and severe decrease of personal accomplishment was detected in $34.2 \%, 26.1 \%$ and $39.7 \%$ of the respondents, respectively (Table 2).

\section{Risk factors of burnout}

Six variables had significant effect on emotional exhaustion $\left(R^{2}=0.119\right.$ for the total model): number of daily working hours, age, number of workplaces and type of primary workplace (in/out-patient department/GP/others). Number of daily working hours had the strongest effect, which was followed by the age of the respondent and inpatient practice and general practice as primary workplace (Table 3).
Table 1 Specialization

\begin{tabular}{|c|c|c|}
\hline Specialization & Number & Percent \\
\hline Addictology & 256 & 6.0 \\
\hline $\begin{array}{l}\text { Jawbone, oral, maxillar and mandibular } \\
\text { bones surgery }\end{array}$ & 5 & 0.1 \\
\hline Internal medicine & 849 & 19.7 \\
\hline Dermatology & 74 & 1.7 \\
\hline Paediatrics & 535 & 12.4 \\
\hline $\begin{array}{l}\text { Physical medicine and rehabilitic } \\
\text { medicine }\end{array}$ & 16 & 0.4 \\
\hline Occupational medicine & 103 & 2.4 \\
\hline Otolaryngology & 98 & 2.3 \\
\hline Gastroenterology & 1 & 0.0 \\
\hline Geriatrics & 2 & 0.1 \\
\hline Paediatric and youth psychology & 9 & 0.2 \\
\hline Paediatric dentistry & 3 & 0.1 \\
\hline Paediatric surgery & 3 & 0.1 \\
\hline Family Medicine (general practice) & 484 & 11.2 \\
\hline Defence and catastrophe medicine & 2 & 0.0 \\
\hline Vasculosurgery & 5 & 0.1 \\
\hline Forensic medicine & 16 & 0.4 \\
\hline Infectology & 18 & 0.4 \\
\hline Cardiology & 9 & 0.2 \\
\hline Endodontic and prosthetic dentistry & 5 & 0.1 \\
\hline Preventive and public medicine & 50 & 1.2 \\
\hline Neurology & 143 & 3.3 \\
\hline Nuclear medicine (isotopdiagnostic) & 14 & 0.3 \\
\hline Orthopaedics-traumatology & 94 & 2.2 \\
\hline Medical laboratory diagnostics & 114 & 2.6 \\
\hline Medical microbiology & 17 & 0.4 \\
\hline Oxyology (ambulance medicine) & 47 & 1.1 \\
\hline Patology & 98 & 2.3 \\
\hline Psychiatry & 187 & 4.3 \\
\hline Radiology & 201 & 4.7 \\
\hline Aviation medicine & 5 & 0.1 \\
\hline Rheumatology & 79 & 1.8 \\
\hline Surgery & 283 & 6.6 \\
\hline Parodontology & 3 & 0.1 \\
\hline Ophtalmology & 117 & 2.7 \\
\hline Cardiosurgery & 2 & 0.1 \\
\hline Obstetrics and gynaecology & 166 & 3.8 \\
\hline Transfusiology & 10 & 0.2 \\
\hline Pulmonolgy & 126 & 2.9 \\
\hline Urology & 55 & 1.3 \\
\hline All & 4306 & 100.0 \\
\hline
\end{tabular}


Table $2 \mathrm{MB}$ subscales in the physician sample

\begin{tabular}{llll}
\hline & $\begin{array}{l}\text { Emotional exhaustion } \\
\%(n=4514) \\
\text { and cumulative } \\
\text { percent }\end{array}$ & $\begin{array}{l}\text { Depersonalization } \\
\%(n=4477) \text { and } \\
\text { cumulative percent }\end{array}$ & $\begin{array}{l}\text { Personal } \\
\text { accomplishment } \\
\%(n=4487)\end{array}$ \\
\hline Mild & $49.4(2229) 49.4$ & $57.3(2566) 57.3$ & $34.2(1534) 34.2$ \\
Moderate & $27.1(1225) 76.5$ & $23.7(1062)$ & $26.1(1172) 60.3$ \\
Severe & $22.2(1060) 100$ & $19(849) 100$ & $39.7(1781) 100$ \\
\hline
\end{tabular}

In case of depersonalization, six significant variables entered the model $\left(R^{2}=0.134\right)$. Age had the strongest (negative) effect, followed by gender (women were at smaller risk to be affected by depersonalization), doing shift work, working primarily at a private service provider (negative correlation) and marital status (lower DP scores for those who lived in a partner relationship (Table 3).

The effect of five variables proved to be significant in case of decreased personal accomplishment $\left(R^{2}=0.034\right)$. Number of workplaces, doing shift work, marital status and working as a GP had the strongest effect (Table 3). Personal accomplishment decreased in line with increasing number of workplaces, doing shift work and working as a GP (Table 3).

\section{Risk factors of the intention to work abroad}

Primary aim of our study was to examine the effect of the three dimensions of burnout on the decision to work abroad. In the first step, we examined the correlation between EE, DP, PA and the willingness to work abroad. In case of EE and DP, there was a significant correlation $(p<0.000$ and $p<0.004$, respectively). In case of PA, the correlation was not significant $(p<0.204)$. In the next step, we built a logistic linear model to unveil the association between EE and DP and the willingness to migrate. In binary logistic regression analysis, binary variable of willingness to migrate was used as dependent variable, while independent variables were gender, age, type of workplace, daily working hours, doing shift work and marital status. After controlling to these variables, EE, beside other traditional risk factors, turned out to be an important explanatory factor. The result of the analysis showed that depersonalization had tendency-like effect on the willingness to migrate (Table 4).

\section{Discussion}

We investigated work-related risk factors of burnout and the association between burnout and one's willingness to migrate in our nationwide, representative survey of Hungarian physicians. We found that decreased personal accomplishment was the most prominent of all three dimensions of burnout among them. Moderate or severe level was reached by $65.1 \%$ of the respondents on PA. This was followed by EE, where moderate and severe level was reached by $49 \%$. On the DP, moderate or high level was reached by approximately $46 \%$. Heavy workload (more than 40 working hours a week and having more than one workplace), young age and doing shift work correlated significantly with EE, which is the core dimension of burnout. These results are in line with the international trends: heavy workload (daily working hours, doing shift work) and young age were associated with high scores of all dimensions of burnout [27, 28].

Young physicians' cohort (in our study, single males under 35 years) is at extreme risk of burnout. However, previous studies found rather conflicting results concerning the correlation between age, burnout and working experience of physicians. There are studies

Table 3 Linear regression analytic model of burnout

\begin{tabular}{|c|c|c|c|c|c|}
\hline Explanatory variables of EE & Adjusted beta & Explanatory variables of DP & Adjusted beta & Explanatory variables of PA & Adjusted beta \\
\hline Constant & & Constant & & Constant & \\
\hline Age & -.168 & Age & $-.299 * * *$ & Age & NS \\
\hline Gender & NS & Gender & $-.142^{* * *}$ & Gender & NS \\
\hline Shift work & NS & Shift work & $0.76^{* * *}$ & Shift work & $.076^{*}$ \\
\hline In-patient practice & $.097^{* * *}$ & In-patient practice & NS & Type of workplace & NS \\
\hline Outpatient practice & NS & Outpatient practice & NS & Outpatient practice & $.051^{*}$ \\
\hline GP & $.064^{* *}$ & GP & NS & GP & $.078^{*}$ \\
\hline Other & $-.038^{* * *}$ & Other & $0.53^{* *}$ & Other & NS \\
\hline Number of workplaces & $0.53^{* *}$ & Number of workplaces & NS & Number of workplaces & $.081^{* *}$ \\
\hline Marital status & NS & Marital status & $-.049^{*}$ & Marital status & $.074^{* * *}$ \\
\hline Daily working hours & $.206^{* * *}$ & Daily working hours & $-.047^{*}$ & Daily working hours & $.051^{*}$ \\
\hline$p$ value for the full model & $p<0.001$ & $p$ value for the full model & $p<0.001$ & $p$ value for the full model & $p<0.001$ \\
\hline Adjusted $R^{2}$ & 0.119 & Adjusted $R^{2}$ & 0.134 & Adjusted $R^{2}$ & 0.034 \\
\hline
\end{tabular}

NS not significant

${ }^{*} p<0,05,{ }^{* *} p<0,01$, ${ }^{* * *} p<0,001$ 
Table 4 The association between moderate and high EE and $\mathrm{DP}$ and the willingness to migrate

\begin{tabular}{lll}
\hline Dependent variables & Unadjusted OR $(95 \% \mathrm{Cl})$ & Adjusted OR $(95 \% \mathrm{Cl})^{*}$ \\
\hline $\mathrm{EE}$ & $1.581^{* * * *}(1.431-1.732)$ & $1.432^{* * * *}(1.216-2.150)$
\end{tabular}

$\mathrm{DP}$ $1.403^{* *}(1.281-2.110) \quad 1.016^{* * * *}(0.957-1.248)$

*Adjusted for age, gender, number of workplaces, daily working hours, shift work and marital status

${ }^{* *} p<0.05$

${ }^{* * *} p<0.01$

$* * * * 00.001$

*****NS not significant

that showed that the youngest, entrant age group was mostly affected by burnout. According to their results, heavy physical and mental burden, the weight of responsibility along with the lack of control over one's work, sleep deprivation and decreasing recreation time resulted in severe mental vulnerability of young physicians [29-31]. The authors of a Belgian study found significantly elevated cortisol levels in residents, which was interpreted as an obvious sign of high stress response [32]. Although a certain level of stress on young physicians helps effective and motivated coping, chronic stress burden leads to decreasing motivation and non-adaptive coping mechanisms, such as suicidal ideation, psychosomatic disorders, etc. [33, 34]. This is in line with the findings of another study: high level of perceived stress was reported by more than $50 \%$ of young doctors [35]. In contrast, Dyrbye et al. found in one of their latest studies that physicians having worked for 11-20 years were the least satisfied with their chosen specialization, and they had the highest scores generally on burnout scales, especially on EE [36].

Our multivariate analysis showed that heavy workload and having more than one workplace indirectly increase the risk of burnout, whereas emotional exhaustion and depersonalization dimensions of burnout have direct impact on the willingness to migrate. The World Health Organization in its 2008 analysis found that the following factors have the most severe impact on health care workers' migration and turnover from work: heavy or dangerous working conditions, insufficient resources, economic instability and the lack of career options [37]. The report stressed 'heavy working conditions' which seem to be key factors in the process of burnout [38]. However, our analysis highlighted that the key dimension of burnout (emotional exhaustion) had an obvious impact on the willingness to migrate. This is in line with the conclusions of the meta-analysis of Lee et al.: there is a strong, positive correlation between burnout and migration [39]. Pantenburg et al. also found in their study of German physicians that severe emotional exhaustion and depersonalization increased the odds of working abroad [40]. Previous studies showed that dissatisfaction with one's job increased the risk of turnover from the health care sector [41]. A meta-analysis from 2014 found that burnout was in correlation with the length of sick leave and the possibility of turnover from the present workplace [19]. Ruitemburg et al. reported that physicians having reached high scores on EE and DP perceived their own personal accomplishment significantly lower [42].

The unique approach of our study is the explicit association between burnout and the willingness to migrate, an issue investigated by only a handful of studies. The relatively low response rate is a limitation; however, multi-dimensional weighting was aimed to create respondent groups that were more representative. A further limitation is that we used a single-item tool for the assessment of the willingness to migrate. According to our latest survey, the willingness to work abroad is decreasing. (2013, $16.7 \%$ vs. 2017, 10.2\%) [43].

\section{Conclusion}

Studies on malpractice cases, hospital infections and migration highlighted that prevention of burnout was the most cost-effective tool of health policy. Prevention of burnout has proved to be feasible both on organizational or individual level [44-46]; therefore, it could play an enormous role in the effectiveness of the health care system. Results of our study showed that burnout can be seen as a consequence of one's dissatisfaction with their working conditions. Nevertheless, emotional exhaustion equals not only dissatisfaction with one's working conditions but also a severe emotional burden that derives from a caregiver's work in general, which suggests that this is a quite complex phenomenon. The number of physicians who take on a job abroad is much less than those who plan to, in reality. This fact might confirm the assumption that the planning to work abroad is a possible coping strategy against burnout. Idealising another workplace can be a way to handle the matter of emotional exhaustion.

We can also assume that there is a circular causality between burnout and the willingness to migrate. Burnout increases the willingness to work abroad, whereas contemplating migration might evoke a certain degree of depersonalization in caregivers who are in a dilemma.

\footnotetext{
Abbreviations

DP: Depersonalization subscale; EE: Emotional exhaustion subscale; GP: General practice; MBI: Maslach Burnout Inventory; OR: Odds ratio; PA: Personal accomplishment subscale; SD: Standard deviation
}

\section{Authors' contributions}

ZSGY participated in data analysis and interpretation, wrote the manuscript, read and approved the final version. DD participated in data interpretation, read and approved the final version of the manuscript. EG participated in planning and designing of the study and approved the final version of the manuscript. All authors read and approved the final manuscript. 


\section{Ethics approval and consent to participate}

The study was approved by the Ethics Committee of the Semmelweis University, Budapest. (ref. number: 60/2013). Our study design included anonymous and voluntary answers to online questionnaires from physicians, but no invasive sampling methods or other similar techniques were applied; thus, there was no need for an informal consent from participants. According to the Ethics Committee of the Semmelweis University's statement, 'no informal consent is necessary when conducting researches in the field of social sciences'. Our research was conducted in full accordance with the World Medical Association Declaration of Helsinki.

\section{Consent for publication}

Not applicable.

\section{Competing interests}

The authors declare that they have no competing interests.

\section{Publisher's Note}

Springer Nature remains neutral with regard to jurisdictional claims in published maps and institutional affiliations.

\section{Author details}

${ }^{1}$ Institute of Behavioural Sciences, Semmelweis University, Nagyvárad square 4, Budapest H-1089, Hungary. '2Department of Obstetrics and Gynecology, Healthcare Service Centre of Csongrád County, Kórház st. 2, Makó H-6900, Hungary. ${ }^{3}$ Health Services Management Training Centre, Semmelweis University, Kútvölgyi st 2, Budapest H-1125, Hungary.

Received: 25 August 2017 Accepted: 27 July 2018

Published online: 10 August 2018

\section{References}

1. Aluttis C, Bishaw T, Frank MW. The workforce for health in a globalized context--global shortages and international migration. Glob Health Action. 2014;7:23611.

2. International Migration of Health Workers 2016. http://www.oecd.org/ migration/mig/44783473.pdf. Accesssed 5 July 2018.

3. Eke E, Girasek E, Szócska, M. From melting pot to laboratory of change in central Europe: Hungary and health workforce migration. In: Wismar, M. Maier, C. B. - Glinos, I. A. Dussault, G. Figueras J: Health professional mobility and health systems: Evidence from 17 European countries. Observatory studies series, 23. Geneva, World Health Organization. 2011

4. Ognyanova D, Maier CB, Wismar M, Girasek E, Busse R. Mobility of health professionals pre and post 2004 and 2007 EU enlargements: evidence from the EU project PROMeTHEUS. Health Policy. 2012;108(2-3):122-32. https://doi.org/10.1016/j.healthpol.2012.10.006. Epub 2012 Nov 13.

5. Action Plan for the EU Health Workforce. Strasbourg 2012. https://ec.europa. eu/health//sites/health/files/workforce/docs/staff_working_doc_healthcare_ workforce en.pdf. Letöltve: 2018.01.14. Accesssed 5 July 2018.

6. ENKK 2016: Human Resource report of the Health Sector. [Beszámoló az egészségügyi ágazat humánerőforrás helyzetéről]. Available from: https:// www.enkk.hu/hmr/documents/beszamolok/HR_beszamolo_2015.pdf. [Hungarian]. Accesssed 5 July 2018.

7. Lóránth I. Few patient, unviable praxis. [Kevés páciens, életképtelen praxis] Orvosok Lapja. 2016;(4):14-6. [Hungarian]

8. Hárs Á Simon D. Why leave the doctors and what for stay at home? [Miért mennek el az orvosok - és miért maradnának itthon? ]- I. rész Külgazdaság, LX. évf., 2016. május-június 3-26. [Hungarian].

9. Girasek E, Csernus R, Ragány K, Eke E. Migration in the health care system. [Migráció az egészségügyben.], vol. 173. Hungarian: Magyar Tudomány; 2013. p. 3. 292-298.

10. Zs G, Birkás E, Sándor I. Career motivation and burnout among medical students in Hungary - could altruism be a protection factor? BMC Medical Education. 2016;16(182):8 p Paper. https://doi.org/10.1186/s12909-016-0690-5

11. Freudenberger HJ. Staff burn-out. J Soc Issues. 1974:30:159.

12. Maslach C. A multidimensional theory of burn-out. In: Cooper CL, editor. Theories of organizational stress. New York: Oxford University Press; 1998. p. 68-85.

13. Leiter MP, Shaughnessy K. The areas of worklife model of burn-out: tests of mediation relationships. Ergonomia. 2006;28:327-41.
14. Shanafelt TD, Bradley KA, Wipf JE, et al. Burnout and self-reported patient care in an internal medicine residency program. Ann Intern Med. 2002; 136(5):358-67.

15. Prins JT, van der Heijden FM, Hoekstra-Weebers JE, et al. Burnout, engagement and resident physicians' self-reported errors. Psychol Health Med. 2009:14(6):654-66.

16. Cimiotti JP, Aiken LH, Sloane DM, et al. Nurse staffing, burnout, and health care-associated infection. Am J Infect Control. 2012;40(6):486-90.

17. Salyers MP, Bonfils KA, Luther L, Firmin RL, White DA, Adams EL, Rollins AL. The relationship between professional burnout and quality and safety in healthcare: a meta-analysis. J Gen Intern Med. 2017;32(4):475-82.

18. Dewa CS, Loong D, Bonato S, Thanh NX, Jacobs P. How does burnout affect physician productivity? A systematic literature review. BMC Health Serv Res. 2014;14:325

19. Dewa CS, Jacobs P, Thanh NX, Loong D. An estimate of the cost of burnout on early retirement and reduction in clinical hours of practicing physicians in Canada. BMC Health Serv Res. 2014:14:254

20. Moreno-Jiménez B, Gálvez-Herrer M, Rodríguez-Carvajal R, Sanz Vergel Al. A study of physicians' intention to quit: the role of burnout, commitment and difficult doctor-patient interactions. Psicothema. 2012;24:263-70.

21. Zhang $Y$, Feng $X$. The relationship between job satisfaction, burnout, and turnover intention among physicians from urban state-owned medical institutions in Hubei, China: a cross-sectional study. BMC Health Serv Res. 2011;11:235

22. Kellerman SE, Herold J. Physician response to surveys. A review of the literature. Am J Prev Med. 2001:20(1):61-7.

23. Flanigan TS, McFarlaine $\mathrm{E}$, Cook S. Conducting survey research among physicians and other medical professionals - a review of current literature. https://www.amstat.org/sections/srms/proceedings/y2008/Files/flanigan.pdf. Accessed 14 Dec 2015

24. KSH Statistical Yearbook of Hungary 2011. [Központi Statisztikai Hivatal Egészségügyi Statisztikai Évkönyv 2011]. Budapest: KSH; 2013 [Hungarian].

25. Maslach C, Jackson SE, Leiter MP. Maslach burn-out inventory manual. 3rd ed. Palo Alto: Consulting Psychologist Press: 1996

26. Ádám S, Mészáros V. Psychometric properties and health correlates of the Hungarian Version of the Maslach Burn-out Inventory - human services survey (MBI-HSS) among physicians. Mentálhigiéné és Pszichoszomatika. 2012;2(13):127-45. [Hungarian]

27. Arora M, Asha S, Chinnappa J, et al. Review article: burnout in emergency medicine physicians. Emerg. Med. Australas. 2013;25(6):491-5.

28. Hyman SA, Michaels DR, Berry JM, et al. Risk of burnout in perioperative clinicians: a survey study and literature review. Anesthesiology. 2011;114(1): 194-204.

29. West CP, Shanafelt TD, Kolars JC. Quality of life, burnout, educational debt, and medical knowledge among internal medicine residents. JAMA. 2011; 306(9):952-60

30. Buddeberg-Fischer B, Klaghofer R, Stamm M, et al. Work stress and reduced health in young physicians: prospective evidence from Swiss residents. Int. Arch. Occup. Environ. Health. 2008:82(1):31-8.

31. Tyssen R, Vaglum P. Mental health problems among young doctors: an updated review of prospective studies. Harv. Rev. Psychiatry. 2002;10(3):154-65.

32. Coeck C, Jorens PG, Vandevivere J, et al. ACTH and cortisol levels during residency training. N. Engl. J. Med. 1991:325(10):738.

33. Aminazadeh N, Farrokhyar F, Naeeni A. Is Canadian surgical residency training stressful? Can. J. Surg. 2012;55(4):S145-51.

34. Rada RE, Johnson-Leong C. Stress, burnout, anxiety and depression among dentists. J. Am. Dent. Assoc. 2004;135(6):788-94.

35. Sameer-ur-Rehman, Kumar R, Siddiqui N, et al. Stress, job satisfaction and work hours in medical and surgical residency programmes in private sector teaching hospitals of Karachi, Pakistan. J. Pak. Med. Assoc. 2012;62(10):1109-12.

36. Dyrbye LN, Varkey P, Boone SL, et al. Physician satisfaction and burnout at different career stages. Mayo Clin. Proc. 2013;88(12):1358-67.

37. Buchan J. How can the migration of health service professionals be managed so as to reduce any negative effects on supply? Copenhagen: World Health Organization; 2008. http://www.who.int/whr/2006/en/. Accesssed 5 July 2018.

38. Wallace JE, Lemaire JB, Ghali WA. Physician wellness: a missing quality indicator. Lancet. 2009;374:1714-21. https://doi.org/10.1016/S01406736(09)61424-0.

39. Lee RT, Seo B, Hladkyj S, Lovell BL, Schwartzmann L. Correlates of physician burnou across regions and specialties: a meta-analysis. Hum Resour Health. 2013;11:48. 
40. Pantenburg B, Luppa M, König HH, Riedel-Heller SG. Burnout among young physicians and its association with physicians' wishes to leave: results of a survey in Saxony, Germany. J Occup Med Toxicol. 2016;11:2.

41. Landon BE, Reschovsky JD, Pham HH, Blumenthal D. Leaving medicine. The consequence of physician dissatisfaction. Med. Care. 2006;44:234-42.

42. Ruitenburg MM, Frings-Dresen MH, Sluiter JK. The prevalence of common mental disorders among hospital physicians and their association with self-reported work ability: a cross-sectional study. BMC Health Serv. Res. 2012;12:292-8.

43. Győrffy Z, Nagy F, Girasek E. Hungarian physician study 2017. Orvosok Lapja 2018;(1). [Hungarian].

44. Regehr C, Glancy D, Pitts A, LeBlanc VR. Interventions to reduce the consequences of stress in physicians: a review and meta-analysis. J Nerv Ment Dis. 2014;202:353-9.

45. West CP, Dyrbye LN, Rabatin JT, Call TG, Davidson JH, Multari A, et al. Intervention to promote physician well-being, job satisfaction, and professionalism: a randomized clinical trial. JAMA Intern Med. 2014;174:527-33.

46. Eckleberry-Hunt J, van Dyke A, Lick D, Tucciarone J. Changing the conversation from burnout to wellness: physician well-being in residency training programs. J Grad Med Educ. 2009;1:225-30.

Ready to submit your research? Choose BMC and benefit from:

- fast, convenient online submission

- thorough peer review by experienced researchers in your field

- rapid publication on acceptance

- support for research data, including large and complex data types

- gold Open Access which fosters wider collaboration and increased citations

- maximum visibility for your research: over $100 \mathrm{M}$ website views per year

At $\mathrm{BMC}$, research is always in progress.

Learn more biomedcentral.com/submissions 